\title{
新しい柱脚機構を有する鉄骨ラーメン骨組の終局耐震能力 及び鉄骨柱支点部の作用力の算定法 \\ ESTIMATION OF SHEAR AND AXIAL FORCE FOR STEEL COLUMN JOINTS AND SEISMIC STRENGTH OF MULTI-STORY STEEL MOMENT RESISTING FRAMES WITH NEW COLUMN SUPPORT SYSTEM
}

\author{
木 村 祥 裕*，金田勝 徳**，和田章*** \\ Yoshihiro KIMURA, Katsunori KANEDA and Akira WADA
}

\begin{abstract}
In the steel frames, the column base is allowed to yield after beam yielding subjected to large earthquake in Japanese design codes such as "The Building Standard Low of Japan" by Building Center of Japan. If the frames have unexpected seismic horizontal force, the soft story mechanism may occur. To prevent the plastic collapse of the column on $1^{\text {st }}$ story, our previous paper suggested the new column support system on $1^{\text {st }}$ story, which consist of the reinforced concrete downside column and the steel topside column. In this paper, the virtual work method is applied to estimate the damage distribution and the collapse deformation capacity of the steel moment resisting frames with these support systems, and the shear and axial demands the column joints on $1^{\text {st }}$ story are clarified.
\end{abstract}

Keywords: Steel Moment Resisting Frame, Beam Yielding Mechanism, Virtual Work Method, Shear Force of Column, Axial Force of Column, Plastic Deformation Capacity 鉄骨ラーメン骨組，全層梁降伏型メカニズム，仮想仕事法，作用せん断力，作用軸力，塑性変形性能

1. 序

梁降伏型メカニズムを形成する鉄骨ラーメン構造物の保有水平耐 力設計では，中程度の地震に対しては梁のみを降伏させ，大地震で は柱脚部の降伏も許容されている ${ }^{1)}$ 。

E-Defenseによる実大 4 層鉄骨ラーメン構造物の倒壊実験 ${ }^{2}$ では, 建築基準法に準拠した構造物に 1995 年兵庫県南部地震 JR 鷹取駅 記録の $100 \%$ の地震動を入力した際，最下層柱の脚部及び柱頭で 局部座屈を生じ, 最下層に損傷集中したため, 構造物は倒壊した。 すなわち, 設計時に想定した降伏メカニズムと終局時（倒壊時） のメカニズムは異なり，優れた耐震性能を有する剛接合鉄骨ラー メン構造物であっても，終局時には各梁端で十分な塑性変形性能 を発揮できず，不安定な力学挙動となることが示された。

著者らは，これまでに鉄骨ラーメン構造が地震時に梁のみの損傷 を許容し，最下層柱の脚部を含めた柱の降伏を防ぐために，図 1(a) に示すような新しい柱脚機構として層中間型柱脚機構を提案した ${ }^{3)-6)}$ 。 この方法では， $\mathrm{RC}$ 基礎梁から $\mathrm{RC}$ 柱を立ち上げ，所定の高さで鉄骨 柱と接合する。柱脚部は, $\mathrm{RC}$ 構造のため, 高い剛性と耐力を有する。 下部 $\mathrm{RC}$ 柱と上部鉄骨柱の接合部である鉄骨柱支点部をピン接合と することで，柱脚部への過度の応力集中を避けることができる。鉄 骨柱支点部については，ベースプレート（シアプレート）とアンカ 一ボルトを緊結し，鉄骨柱支点部での回転を許容する。この鉄骨柱 支点部には，柱に作用するせん断力に対してはシアプレートで抵抗 し，軸方向の引張力に対してはアンカーボルトで抵抗する方法を用
いた。さらに，鉄骨柱支点部での回転を許容するために，鉄骨柱下 端と $\mathrm{RC}$ 柱上端に保護プレートを設け, テーパー付き座金を設ける方 法とした ${ }^{5}$ 。文献 3)，4)，6)では, 静的増分解析及び地震応答解析に より，このような柱脚機構を有する鉄骨ラーメン骨組が全層梁降伏 型メカニズムとなる条件や梁もしくは柱が最大耐力となるときの骨 組の保有水平耐力や最大層間変形角, 寸なわち終局耐震能力を明ら かにした。

一方，ラーメン骨組の保有水平耐力の算定法として，塑性極限解 析が挙げられる77。従来の埋め込み型柱脚鉄骨ラーメン骨組では, 崩 壊機構を適切に仮定することで，解の上界や下界を見出すことがで

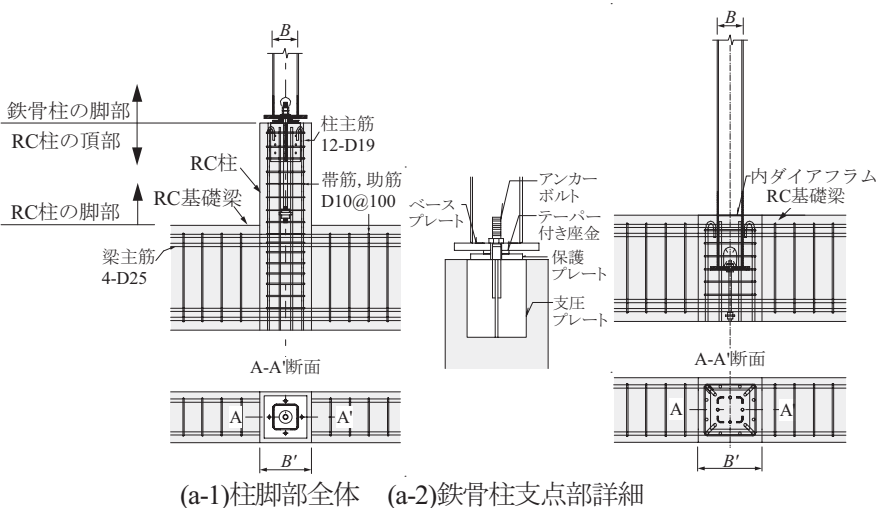

(a) 層中間型柱脚

図 1 最下層の柱脚形式

\footnotetext{
* 東北大学未来科学技術共同研究センター 教授・博士 (工学 $)$

** 構造計画プラス・ワン 代表 日本大学 特任教授・博士 (工学)

*** 東京工業大学 名誉教授. 工博
}

Prof., New Industry Creation Hatchery Center, Tohoku University, Dr. Eng.

Structural Design PLUS ONE Co., Ltd.

Prof., Nihon University, Dr. Eng.

Prof. Emeritus, Tokyo Institute of Technology, Dr. Eng. 
きるものの, 梁降伏後, 柱降伏の発生時期が明確でなく, 特に最下 層柱脚部が降伏した後，損傷が集中することから鉄骨ラーメン骨組 の降伏メカニズムや保有水平耐力の算定には，有限要素法等の静的 増分解析を行う必要がある。また, 前述の倒壞実験 ${ }^{2}$ のように, 様々 な要因により設計時に想定した降伏メカニズムと終局メカニズムが 異なることから，終局時の崩壞機構を適切に設定することは容易で はない。しかし，図 1 に示す層中間型柱脚機構を有する鉄骨ラーメ ン骨組であれば，最下層柱の断面を大きくせずとも大地震時に梁の みが降伏し，最下層柱脚の降伏を防ぐことができることを示してい

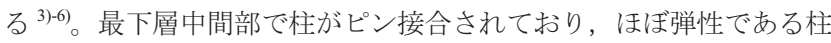
により高さ方向に梁端曲げモーメントを均一化する効果があること から，増分解析を用いなくても，最下層中間部を基点とした外力仕 事と内部エネルギーの釣り合いから仮想仕事法により最大層間変形 角 $0.02,0.03$ や部材崩壊時の保有水平耐力を求められるものと思わ れる。

本論文では，層数やスパン数，柱梁曲げ耐力比等をパラメータと して, 静的増分解析や地震応答解析により求めた終局時及び部材崩 壊時の保有水平耐力と仮想仕事法による保有水平耐力を比較し，保 有水平耐力の算定に仮想仕事法の適用を試みる。さらに，鉄骨柱支 点部や $\mathrm{RC}$ 柱の要求性能として鉄骨柱支点部に作用するせん断力や 軸力を明らかにし，層中間型柱脚機構を有する鉄骨ラーメン骨組に 要求される性能を明らかにする。

\section{2. 層中間型柱脚機構を有する中低層鉄骨ラーメン骨組の保有水平 耐力に対する仮想仕事法の適用}

本章では，外力仕事と内部エネルギーの釣り合いから架構の保有 水平耐力を簡略的に求め, 静的増分解析により終局耐力時の塑性义 カニズムや保有水平耐力と比較する。

\section{1 仮想仕事法による中低層鉄骨ラーメン骨組の保有水平耐カの 算定手順}

図 2 に示すような層中間型柱脚を有する多層多スパン $(n$ 層, $m$ スパン）ラーメン骨組が， $\mathrm{A}_{\mathrm{i}}$ 分布により算出した静的地震外力 $F$ を各層に受けたときの崩壊メカニズムを想定する。想定される梁 の塑性ヒンジ発生位置を○で示している。仮想仕事法による架構 の保有水平耐力の算出方法は以下の通りである。

1)梁の抵抗曲げモーメントの合計值 $\Sigma M_{r}$ の算出

全層で梁の抵抗曲げモーメントが全塑性状態となるとき，歪硬 化による耐力上昇率 (歪硬化係数) $\tau$ を考慮すると, 抵抗曲げモ一 メントの最大值 $M_{r, i j}$ は(1)式となる。

$$
M_{r, i j}=\sum_{j=1}^{m} \sum_{i=1}^{n} \tau \cdot M_{p, i j}
$$

ここで, $M_{p, i j}$ は $i$ 層 $j$ スパンにおける梁の全塑性モーメントであ る。梁の耐力上昇率 $\tau$ は部位ごとに異なるものの, 本柱脚機構を適 用した柱が弾性であれば柱が心棒として機能し，高さ方向に梁端 の曲げモーメントを均一化させる効果がある。そこで，骨組の保 有水平耐力を簡略的に求めるために部材ごとではなく平均值とし て骨組ごとに設定する。

2)転倒モーメントの合計值 $\Sigma M_{q}$ の算出

$\mathrm{A}_{\mathrm{i}}$ 分布より $C_{0}=0.2$ のときの層せん断力 $Q_{i}$ を次式で求め, 水平 外力 $F_{i}$ に換算する。

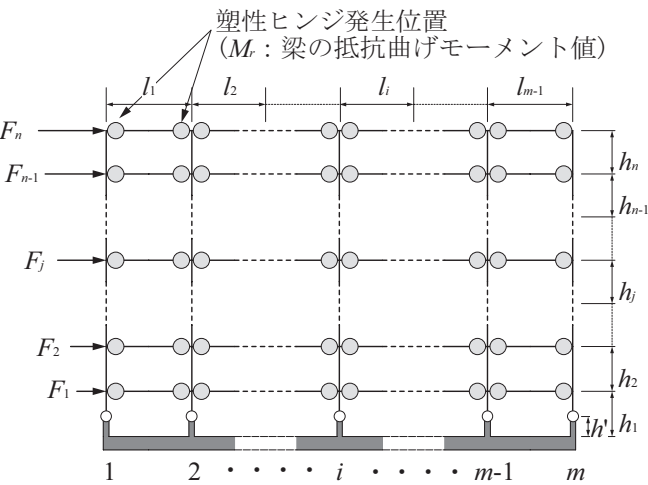

図 2 崩壊メカニズムの設定

$Q_{i}=C_{i} \sum_{j=i}^{N} W_{j}, \quad C_{i}=Z \cdot R_{t} \cdot A_{i} \cdot C_{0}$

ここで, $W_{i}$ は $i$ 層の重量, $C_{i}$ は $i$ 層の層せん断力係数, $Z$ : 地域 係数（ここでは 1 とする）, $R_{t}$ : 振動特性係数, $A_{i}: i$ 層の層せん 断力係数の分布を示寸係数である。

$F_{i}=Q_{i}-Q_{i+1}$

ただし，最上層（ $n$ 層）に作用する水平外力は $F_{n}=Q_{n}$ となる。

転倒モーメントの合計值 $\Sigma M_{q}$ は，それぞれの $F_{i}$ にピン支持であ る鉄骨柱支点部からの距離 $\Sigma h_{i}$ を乗じた值であり，例えば 6 層骨 組みの場合，次式となる。

$$
\begin{aligned}
\sum_{i=1}^{n} M_{q, i}= & F_{6} \cdot\left[h_{6}+h_{5}+h_{4}+h_{3}+h_{2}+\left(h_{1}-h^{\prime}\right)\right]+F_{5} \cdot\left[h_{5}+h_{4}+h_{3}+h_{2}+\left(h_{1}-h^{\prime}\right)\right] \\
& +F_{4} \cdot\left[h_{4}+h_{3}+h_{2}+\left(h_{1}-h^{\prime}\right)\right]+F_{3} \cdot\left[h_{3}+h_{2}+\left(h_{1}-h^{\prime}\right)\right] \\
& +F_{2} \cdot\left[h_{2}+\left(h_{1}-h^{\prime}\right)\right]+F_{1} \cdot\left(h_{1}-h^{\prime}\right)
\end{aligned}
$$

h’は図 2 に示すように最下層鉄骨柱支点部の高さである。

3)抵抗曲げモーメントの合計值 $\Sigma \Sigma \tau \cdot M_{r, i j}$ と転倒モーメントの合 計值 $\Sigma M_{q, i}$ の比較

$C_{v}=0.2 \sum_{j=1}^{m} \sum_{i=1}^{n} \tau \cdot M_{r, i j} / \sum_{i=1}^{n} M_{q, i}(=D s)$

(5)式で求めた值は, 仮想仕事法により求めた骨組のベースシア 係数 $C_{v}$ であり, 骨組の保有性能 $D s$ に相当する ${ }^{1)}$ 。歪硬化を考慮

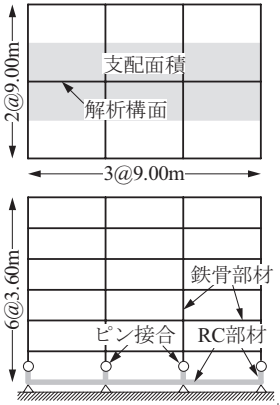

(a) 層中間型柱脚骨組

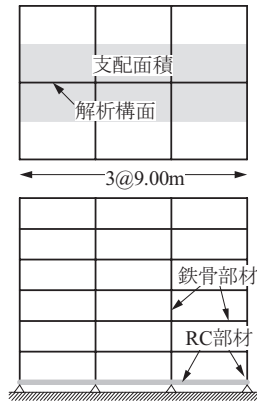

(b) 埋め込み型柱脚骨組

図 3 数值解析モデル

骨組名称の記号

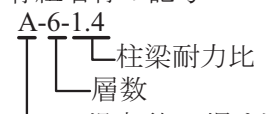

LA:提案型 B:埋め込み型

表 1 材料特性 $\left(\mathrm{N} / \mathrm{mm}^{2}\right)$

\begin{tabular}{|c|c|}
\hline$E_{\text {steel }}$ & $205.8 \times 10^{3}$ \\
\hline$\sigma_{y \text {-steel }}$ & 235.0 \\
\hline$E_{\text {concrete }}$ & $27.3 \times 10^{3}$ \\
\hline$F$ & 36.0 \\
\hline
\end{tabular}

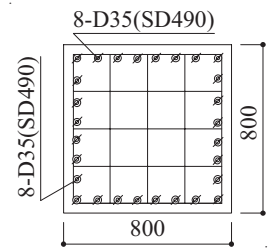

図 46 層骨組の $\mathrm{RC}$ 柱の断 面及び配筋の例(28- D35) 
しない場合は(1)式において $\tau=1.0$ として $M_{r, i j}$ を算出する。なお, ここで得られた值は保有水平耐力の上界となる近似解であるが, 水平変形の増加に伴い, 部材は歪硬化し耐力上昇することから, 耐力上昇率 $\tau$ にり，次節以降，各層間変形角時（最大層間変形角 $0.02 ， 0.03$, 部材崩壊時）での保有水平耐力の算定を試みる。

\section{2 静的地震外力を受ける中低層鉄骨ラーメン骨組の解析概要}

\section{2.1 骨組モデル}

図 3(a)に層中間型柱脚 6 層ラーメン骨組の平面図及び軸組図を示 す。3 9 層ラーメン骨組を対象として静的増分解析により, 2.1 節の 仮想仕事法による保有水平耐力值の妥当性を検証する。また，比較 のため, 図 3(b)に示寸埋め込み型柱脚ラーメン骨組についても数值解 析を行う。基本モデルとしたラーメン骨組は図 3(a)に示すような 3 ス パンであり, 1 スパン $l=9 \mathrm{~m}$, 各層の高さ $h=3.6 \mathrm{~m}$ である。文献 3$)$ で鉄 骨柱支点部の高さ $h$ 'は最下層高さの 0.5 程度が適切であることが示さ れていることから $h^{\prime}=1.8 \mathrm{~m}$ としている。文献 5)で図 1 に示寸鉄骨柱 支点部を含む柱梁部分架構モデルの載荷実験を行い，鉄骨柱支点部 の力学挙動を確認した結果，支点部はほぼピン接合になることを明 らかにした。そこで，本論文における解析モデルでは，鉄骨柱支点 部をピン接合とし, その他の柱梁接合部を剛接合とする。そして, 塑性ヒンジを生じうる梁端及び柱端に弾塑性回転ばね要素を用いる。 また, 文献 3) と同様, 事前に予備解析を行い, 所定の層間変形角 時の最下層下部 RC 柱に作用する軸力と曲げモーメントに対して, $\mathrm{RC}$ 柱がひび割れを生じず，初期剛性を保持するように断面や鉄 筋本数を決定した ${ }^{8)}$ 。例として 6 層骨組の $\mathrm{RC}$ 柱の形状及び鉄筋 の配筋を図 4 に示寸。鉄筋の鋼種をSD490 としている。また, 3 層骨組，9層骨組も同様の解析モデルとしており，鉄筋をSD490 で 28-D35 としている。数值解析には汎用有限要素解析プログラム ABAQUS6.8 を用いる。

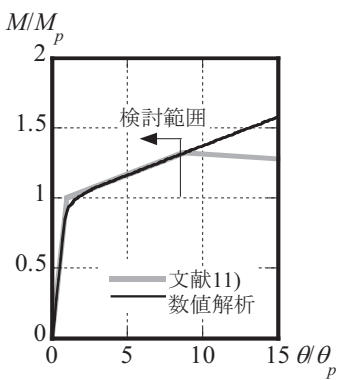

(a)第 1 層柱

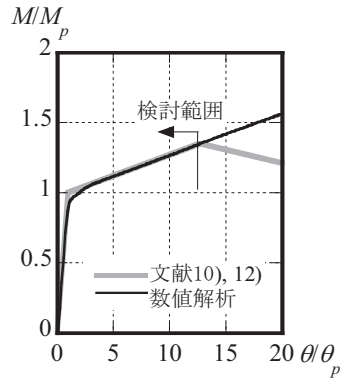

(b)第 1 層梁

図 5 鉄骨部材の $M / M_{p}-\theta / \theta_{p}$ 関係 (6-1.4)

図 3 下に骨組名称の説明を示す。最初の記号が柱脚機構, 2 番目の 数字が層数, 3 番目の数字が梁の全塑性曲げモーメント $M_{p b}$ に対する 柱の全塑性曲げモーメント $M_{p c}$ の割合 $M_{p d} / M_{p b}$ である。ここで, 柱梁 耐力比は節点に関する下限值であり，柱の耐力に及ぼす軸力の影響 は考慮していない。また, 高さ方向に層せん断耐力分布が異なる骨 組の保有水平耐力を検討寸るために, 2 層ごとに部材断面を変更した 骨組を設計した。これらには最初のアルファベットにダッシュをつ けている。

\section{2.2 部材モデル}

表 1 に部材の材料特性を示す。柱及び梁ともに鋼種を SS400 相当 とし, その代表值として鋼材のヤング係数 $E_{\text {steel }}$ を $205.8 \times 10^{3} \mathrm{~N} / \mathrm{mm}^{2}$, 降伏応力 $\sigma_{y-\text { steel }}$ を $235.0 \mathrm{~N} / \mathrm{mm}^{2}$ とし, コンクリートのヤング係数 $E_{\text {concrete }}$ を $27.3 \times 10^{3} \mathrm{~N} / \mathrm{mm}^{2}$, 降伏応力 $F$ を $36.0 \mathrm{~N} / \mathrm{mm}^{2}$ とする。

図 5 に柱梁耐力比 $M_{p c} / M_{p b}=1.4$ の層中間型柱脚 6 層ラーメン骨組の 第 1 層柱及び梁モーメント一回転角関係を示寸。縦軸は, 材端の作 用曲げモーメント $M$ を全塑性モーメント $M_{p}$ で除した $M / M_{p}$ であ る。横軸は, 材端の回転角 $\theta$ を全塑性モーメント時の材端の弾性 回転角 $\theta_{p}$ で除した $\theta / \theta_{p}$ である。各部材の骨格曲線は, 文献 9) 11)

表 2 部材断面 $(\mathrm{mm})$

\begin{tabular}{|c|c|c|c|c|c|c|c|c|c|c|}
\hline 骨組 & \multicolumn{2}{|c|}{$\mathrm{A}-3-1.2, \mathrm{~B}-3-1.2$} & \multicolumn{2}{|c|}{ A-3-1.4, B-3-1.4 } & \multicolumn{2}{|c|}{ A-3-1.6, B-3-1.6 } & \multicolumn{2}{|c|}{$\mathrm{A}^{\prime}-3-1.6$} & \multicolumn{2}{|c|}{$\mathrm{A}-3-1.8, \mathrm{~B}-3-1.8(\mathrm{~A}-3-2.0, \mathrm{~B}-3-2.0)$} \\
\hline Story & Column & Girder & Column & Girder & Column & Girder & Column & Girder & Column & Girder \\
\hline 3 & \multirow{3}{*}{$\square-460 \times 18$} & $\begin{array}{c}\mathrm{H}-550 \times 200 \\
\times 12 \times 16 \\
\end{array}$ & \multirow{3}{*}{$\square-490 \times 18$} & $\begin{array}{c}\mathrm{H}-550 \times 200 \\
\times 12 \times 16 \\
\end{array}$ & \multirow{3}{*}{$\square-500 \times 19$} & $\begin{array}{c}\mathrm{H}-550 \times 200 \\
\times 12 \times 16 \\
\end{array}$ & $\square-500 \times 17$ & $\begin{array}{c}\mathrm{H}-550 \times 200 \\
\times 12 \times 16 \\
\end{array}$ & \multirow{3}{*}{$\begin{array}{c}\square-520 \times 19 \\
(\square-540 \times 20)\end{array}$} & $\begin{array}{c}\mathrm{H}-550 \times 200 \\
\times 12 \times 16 \\
\end{array}$ \\
\hline 2 & & \multirow{2}{*}{$\begin{array}{l}\mathrm{H}-670 \times 260 \\
\times 12 \times 20\end{array}$} & & \multirow{2}{*}{$\begin{array}{c}\mathrm{H}-670 \times 250 \\
\times 12 \times 19\end{array}$} & & \multirow{2}{*}{$\begin{array}{l}\mathrm{H}-650 \times 250 \\
\times 12 \times 19\end{array}$} & \multirow{2}{*}{$\square-500 \times 19$} & \multirow{2}{*}{$\begin{array}{l}\mathrm{H}-650 \times 250 \\
\times 12 \times 19\end{array}$} & & $\begin{array}{c}\mathrm{H}-640 \times 250 \\
\times 12 \times 19\end{array}$ \\
\hline 1 & & & & & & & & & & $\begin{array}{c}(\mathrm{H}-620 \times 260 \\
\times 12 \times 19)\end{array}$ \\
\hline 基礎 & $800 \times 800$ & $1200 \times 800$ & $800 \times 800$ & $1200 \times 800$ & $800 \times 800$ & $1200 \times 800$ & $800 \times 800$ & $1200 \times 800$ & $800 \times 800$ & $1200 \times 800$ \\
\hline 骨組 & \multicolumn{2}{|c|}{ A-6-1.2, B-6-1.2 } & \multicolumn{2}{|c|}{ A-6-1.4, B-6-1.4 } & \multicolumn{2}{|c|}{ A-6-1.6, B-6-1.6 } & \multicolumn{2}{|c|}{$A^{\prime}-6-1.6$} & \multicolumn{2}{|c|}{ A-6-1.8, B-6-1.8 } \\
\hline Story & Column & Girder & Column & Girder & Column & Girder & Column & Girder & Column & Girder \\
\hline 6 & \multirow{3}{*}{$\square-530 \times 20$} & $\begin{array}{c}\text { BH- } 650 \times 220 \\
\times 12 \times 19\end{array}$ & \multirow{3}{*}{$\square-550 \times 20$} & $\begin{array}{c}\mathrm{BH}-650 \times 250 \\
\times 12 \times 19 \\
\end{array}$ & \multirow{3}{*}{$\square-580 \times 21$} & $\begin{array}{c}\mathrm{BH}-650 \times 250 \\
\times 12 \times 19 \\
\end{array}$ & \multirow{2}{*}{$\square-590 \times 18$} & $\begin{array}{c}\mathrm{BH}-600 \times 250 \\
\times 12 \times 16\end{array}$ & \multirow{3}{*}{$\square-600 \times 21$} & $\begin{array}{c}\mathrm{BH}-650 \times 250 \\
\times 12 \times 19\end{array}$ \\
\hline 5 & & \multirow{2}{*}{$\begin{array}{l}\text { BH- } 820 \times 260 \\
\times 12 \times 19\end{array}$} & & \multirow{2}{*}{$\begin{array}{l}\mathrm{BH}-800 \times 260 \\
\times 16 \times 19\end{array}$} & & \multirow{2}{*}{$\begin{array}{c}\mathrm{BH}-770 \times 270 \\
\times 16 \times 19\end{array}$} & & $\begin{array}{c}\mathrm{BH}-750 \times 270 \\
\times 16 \times 18\end{array}$ & & \multirow{2}{*}{$\begin{array}{c}\text { BH- } 760 \times 270 \\
\times 16 \times 19\end{array}$} \\
\hline 4 & & & & & & & $\square-600 \times 20$ & BH- $750 \times 300$ & & \\
\hline 3 & \multirow[b]{2}{*}{$\square-530 \times 24$} & \multirow{2}{*}{$\begin{array}{c}\mathrm{BH}-820 \times 260 \\
\times 12 \times 19\end{array}$} & \multirow[b]{2}{*}{$\square-550 \times 25$} & \multirow{2}{*}{$\begin{array}{l}\mathrm{BH}-800 \times 300 \\
\quad \times 16 \times 22\end{array}$} & & & & $\times 16 \times 20$ & & \\
\hline$\frac{2}{1}$ & & & & & $\square-600 \times 23$ & $\begin{array}{c}\mathrm{BH}-16 \times 22 \\
\times 16 \times 22\end{array}$ & $\square-600 \times 24$ & $\begin{array}{c}\mathrm{BH}-750 \times 330 \\
\times 16 \times 23\end{array}$ & $\square-630 \times 23$ & $\begin{array}{c}\mathrm{BH}-/ 60 \times 310 \\
\times 16 \times 22\end{array}$ \\
\hline 基礎 & $800 \times 800$ & $1200 \times 800$ & $800 \times 800$ & $1200 \times 800$ & $800 \times 800$ & $1200 \times 800$ & $800 \times 800$ & $1200 \times 800$ & $800 \times 800$ & $1200 \times 800$ \\
\hline 骨組 & A-9-1. & B-9-1.2 & A-9-1. & B-9-1.4 & A-9-1. & B-9-1.6 & & -1.6 & A-9- & B-9-1.8 \\
\hline Story & Column & Girder & Column & Girder & Column & Girder & Column & Girder & Column & Girder \\
\hline 9 & & $\begin{array}{c}\mathrm{BH}-650 \times 210 \\
\times 12 \times 19\end{array}$ & & $\begin{array}{c}\mathrm{BH}-650 \times 210 \\
\times 12 \times 19\end{array}$ & & $\begin{array}{c}\mathrm{BH}-630 \times 200 \\
\times 12 \times 19\end{array}$ & $\square-560 \times 19$ & $\begin{array}{c}\mathrm{BH}-630 \times 200 \\
\times 12 \times 19\end{array}$ & & $\begin{array}{c}\mathrm{BH}-630 \times 200 \\
\times 12 \times 19\end{array}$ \\
\hline$\frac{8}{7}$ & $\square-520 \times 20$ & $\begin{array}{c}\text { BH- } 740 \times 300 \\
\times 16 \times 21\end{array}$ & $\square-540 \times 20$ & $\begin{array}{c}\text { BH- } 760 \times 270 \\
\times 16 \times 19\end{array}$ & $\square-560 \times 21$ & $\begin{array}{c}\text { BH- } 700 \times 300 \\
\times 16 \times 20\end{array}$ & $\square-560 \times 21$ & $\begin{array}{c}\mathrm{BH}-700 \times 300 \\
\times 16 \times 20\end{array}$ & $\square-590 \times 21$ & $\begin{array}{c}\mathrm{BH}-700 \times 300 \\
\times 16 \times 20\end{array}$ \\
\hline 6 & & & & & & & $\square-560 \times 25$ & BH-770×300 & & \\
\hline 5 & $\square-530 \times 23$ & $\times 16 \times 22$ & $\square-550 \times 24$ & $\times 16 \times 21$ & $\square-560 \times 25$ & $\times 16 \times 21$ & & $\times 16 \times 21$ & $\square-610 \times 23$ & $\begin{array}{c}\times 16 \times 21 \\
\times 16 \times 0\end{array}$ \\
\hline 4 & & & & & & & $\square-590 \times 24$ & BH- $810 \times 300$ & & \\
\hline 3 & & BH $-850 \times 300$ & & BH- $830 \times 300$ & & BH- $810 \times 300$ & $\square-590 \times 24$ & $\times 16 \times 21$ & & $\mathrm{BH}-800 \times 300$ \\
\hline $\begin{array}{l}2 \\
1\end{array}$ & $\square-550 \times 23$ & $\times 16 \times 22$ & $\square-570 \times 24$ & $\times 16 \times 22$ & $\square-590 \times 25$ & $\times 16 \times 22$ & $\square-590 \times 25$ & $\begin{array}{c}\mathrm{BH}-810 \times 300 \\
\times 16 \times 22\end{array}$ & $\square-610 \times 26$ & $\times 16 \times 22$ \\
\hline 基礎 & $1000 \times 1000$ & $1200 \times 1000$ & $1000 \times 1000$ & $1200 \times 1000$ & $1000 \times 1000$ & $1200 \times 1000$ & $1000 \times 1000$ & $1200 \times 1000$ & $1000 \times 1000$ & $1200 \times 1000$ \\
\hline
\end{tabular}


で柱梁接合部から反曲点までの区間を一部材とした実験式 より求められる。実験式はSS400, SM490 相当の鋼材を対 象としている。本論文では, 骨組内の部材が最大耐力を迎 えた時点を部材崩壊とし，そのときの骨組の最大層間変形 角や保有水平耐力を部材崩壊時の保有性能と定義する。ま た, 図 5(a)の鉄骨柱の骨格曲線は初期軸力時のものであり, 水平外力を受ける場合, 柱は軸力変動を生じる。そして, 軸力変動は柱の塑性変形性能に影響を与えることが既往の

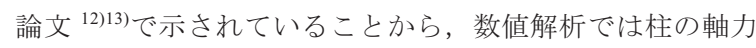
変動を逐次追跡し, その変化した軸力を元に文献 11)の実 験式を用いて最大耐力時の柱の塑性変形性能を再計算する。 文献 11)では, 柱の軸力比が $3 A_{w} / 5 A(\fallingdotseq 0.3)$ よりも大きくな った場合, 式中における幅厚比を 1.25 倍することで塑性変 形性能を低減させており, 本論文でもこの方法を採用する。 ここで, $A_{w}$ は柱のウェブ断面積, $A$ は柱の全断面積である。 なお，静的増分解析では P-ס効果を考慮しているが，梁の 床スラブ効果については考慮していない。

表 2 に 3 9 層ラーメン骨組の部材断面を示す。部材断面を 決定する際には, 保有水平耐力設計に沿って, 同じ層数で 柱梁耐力比が異なる骨組の初期剛性や降伏耐力等, 層せん 断力一層間変形角関係が概ね同等となるように設計した ${ }^{1)}$ 。 本章の解析モデルでは, 柱・梁の断面ともに幅厚比が文献 1) で定められた FA ランクのものを使用し, 柱で 20.0 32.8, 梁でウェブ 41.3 52.7, フランジ 5.3 7.8 であり, 実験式 9) 11)の適用範囲内である。 さらに，文献 4)，6)より同じ損傷メカニズム分布であれば部材崩 壊時（図 5 に示寸最大耐力時）の骨組の最大層間変形角はほぼ等 しくなることが示されており, 同じ層数で柱梁耐力比が異なる骨 組における梁もしくは柱の塑性変形性能をほぼ等しくするため, 幅を $10 \mathrm{~mm}$ 単位で板厚は $1 \mathrm{~mm}$ 単位で設定した。付表 1 に文献 9) 11) より求めた各梁及び柱の最大耐力と塑性変形性能を示しており, 本論 文における梁及び柱の最大耐力は全塑性耐力に対して $M_{\text {max }} / M_{p}$ $=1.33 \sim 1.35(1.51)$ 及び $1.22 \sim 1.34$, 梁及び柱の塑性変形性能は $\theta_{\text {max }} / \theta_{p}=11.9 \sim 12.7$ (18.0)及び 6.34 9.24 の範囲である。()は最上層の梁 の值である。また, $\mathrm{Ai}$ 分布より求めた層せん断力分布となる水平外 力を, 図 2 に示寸ように骨組の左側から与える。その際, $C_{0}=0.2$ のと きの最大層間変形角が $1 / 200$ 以下を満足している。高さ方向に関して は 3 層ごとに, さらに柱梁耐力比 1.6 の骨組については 2 層ごとに部 材断面を変更する。最上階の梁は柱に対して過剩な剛性とならないよ うに, 他の梁の剛性の 5 割程度となる断面を選定しており, 長期荷重 に対する設計を行っていない。

\section{3 層中間型柱脚機構を用いた鉄骨ラーメン骨組の終局メカニズ 么と保有水平耐力}

\section{3.1 層せん断カー層間変形角関係}

図 6 に柱梁耐力比 $M_{p c} / M_{p b}=1.6$ の層中間型柱脚 3 9 層ラーメン 骨組の各層の層せん断力一層間変形角を示す。横軸は各層の層間 変形角 $\delta_{i} / h$, 縦軸は各層のせん断力 $Q_{i}$ を架構の総重量 $W$ と振動特 性係数 $R_{t}$ で除した值 $Q_{1} / W R_{t}\left(=C_{a}\right)$ である。図中の $\triangle, \bigcirc, \square$ は最 大層間変形角 $\delta_{\max } / h=0.01,0.02,0.03$ 時を示寸。図中の灰色の横線 は，仮想仕事法において梁の歪硬化を考慮した場合 $(\tau=1.1,1.3)$ と考慮しない場合 $(\tau=1.0)$ の保有水平耐力係数 $C_{v}$ を示す。図 6(a) は

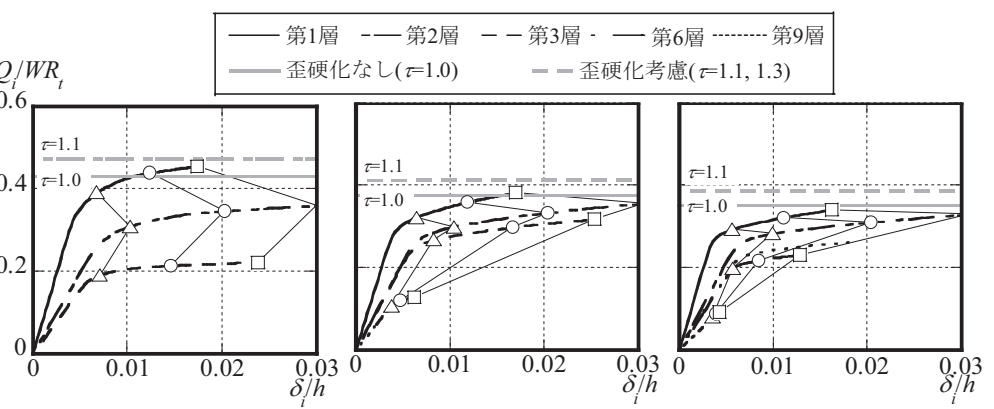

(a-1)3 層骨組

(a-2)6 層骨組 (a) $\delta_{i} / h_{i}=003$ まで

(a-3)9 層骨組

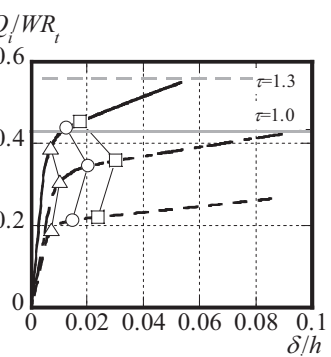

(b-1)3 層骨組

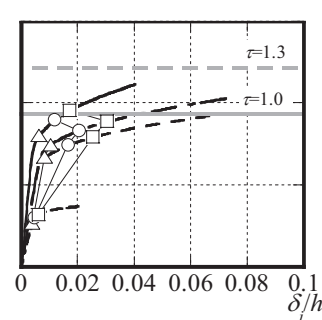

(b-2)6 層骨組 (b)部材崩壊まで

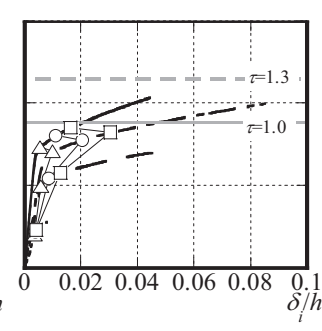

(b-3)9 層骨組
図 6 静的増分解析による層中間型柱脚骨組の層せん断力一層間変形 角関係と仮想仕事法による保有水平耐力の比較 $\left(M_{p c} / M_{p b}=1.6\right)$

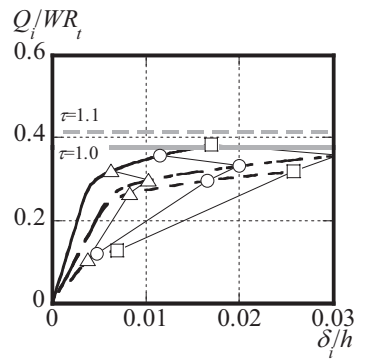

(a-1)2 スパン 6 層骨組

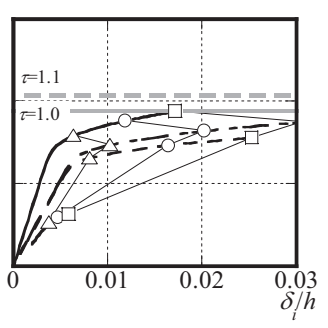

(a-2)4 スパン 6 層骨組

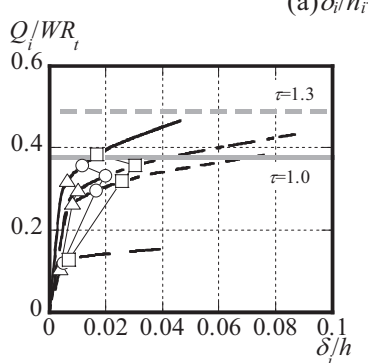

(b-1)2 スパン 6 層骨組

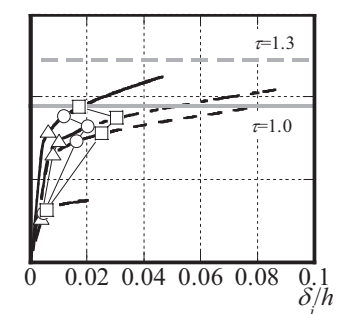

(b-2)4 スパン 6 層骨組 (b)部材崩壊まで

図 7 静的増分解析による層中間型柱脚骨組の層せん断力一層間 変形角関係と仮想仕事法による保有水平耐力の比較 $\left(M_{p c} / M_{p b}=1.6\right)$

最大層間変形角 0.03 までを示し, 図 6(b)は部材崩壊時までを示し ている。(a) $\delta_{\max } / h=0.03$ 時では静的増分解析による保有水平耐力は, 3 層骨組では歪硬化を考慮した $\tau=1.1$ の仮想仕事法の值とほぼ等 しく, 6 層， 9 層骨組では歪硬化を考慮しない $\tau=1.0$ の仮想仕事法 の值とほぼ等しい。これは, $\delta_{\max } / h=0.03$ までに 3 層骨組では全て の梁端でほぼ降伏しているものの, 6 層, 9 層骨組では上層部の梁 端で降伏していない箇所があるためである。(b)では，本論文にお ける梁の最大耐力は全塑性耐力に対して 1.3 倍以上であり, 塑性 変形性能も 12 程度と大きいことから, 部材崩壊時の最大層間変形 角は $\delta_{\text {max }} / h=0.07 \sim 0.09$ と非常に大きく, 多くの梁で最大耐力近くま 


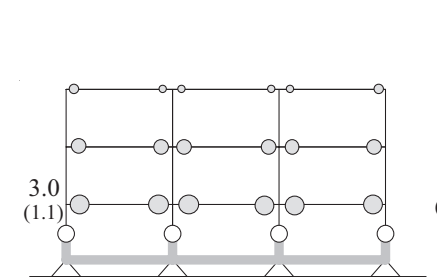

(a-1) 層中間型柱脚骨組

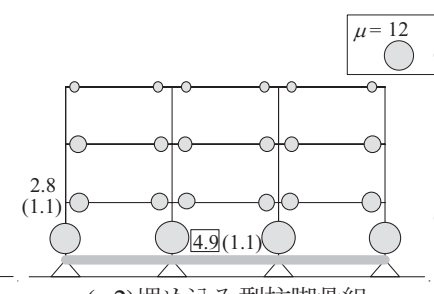

(a-2)埋め込み型柱脚骨組

(a) $\delta_{\max } / h=0.03$ 時

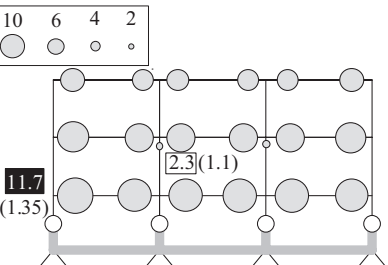

(b-1) 層中間型柱脚骨組

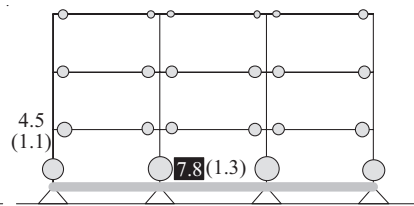

(b-2)埋め込み型柱脚骨組

図 8 柱脚形式が異なる骨組の塑性率分布

で耐力上昇している。そのため, 歪硬化を考慮した $\tau=1.3$ の仮想 仕事法による保有水平耐力と数值解析結果は概水等しい。

図 7 に柱梁耐力比 $M_{p c} / M_{p b}=1.6$ の層中間型柱脚 2, 4 スパン 6 層 ラーメン骨組の各層の層せん断力ー層間変形角を示す。層中間型 柱脚の場合, 梁降伏が先行し, $\delta_{\text {max }} / h=0.03$ までは梁のみが塑性化 している。そして, 柱梁耐力比が大きい側柱のせん断力は中柱に 比べて相対的に大きくないため, 図 6(a-2)の 3 スパン 6 層骨組と 比べて, 初期降伏時や $\delta_{\text {max }} / h=0.03$ 時の層せん断力に違いは見られ ない。つまり, スパン数の違いによらず， 6 層骨組では歪硬化を 考慮しない仮想仕事法により保有水平耐力を評価できる。さらに, 図 7(b-1), (b-2)の部材崩壊時でも一部の中間層で柱が降伏するが, 柱の塑性変形倍率は小さいため, スパン数の違いによらず層せん 断力一層間変形角関係はほぼ等しくなっている。

\subsection{2 骨組の塑性変形倍率分布と保有水平耐力}

図 8 に 3 層ラーメン骨組の最大層間変形角 $\delta_{\text {max }} / h=0.03$ 及び部材崩壊 時の塑性変形倍率分布を示す。図中の数字は最大となる梁の塑性変 形倍率であり, $\square$ で囲まれた数字は最大となる柱の塑性変形倍率で ある。( )の数字は梁及び柱の全塑性モーメントに対する最大曲げモ 一メントの比 $M_{b, \text { max }} / M_{p b}, M_{c, \text { max }} / M_{p c}$ である。また, (b)部材崩壊時で で囲まれた数字は部材崩壊となる梁もしくは柱の塑性変形倍率であ る。図中の灰色の円は降伏した部位であり，白円は鉄骨柱支点部で ある。層中間型柱脚骨組は $\delta_{\text {max }} / h=0.03$ 時には全層梁降伏型メカニズム を形成しており, 最下層では歪硬化により最大 $M_{b, \text { max }} / M_{p b}=1.1$ となっ ている。部材崩壊時には全層で梁降伏するとともに中間層の柱でも 降伏するが，柱の塑性変形倍率は小さい。最下層の梁では歪硬化に より最大 $M_{b, \text { max }} / M_{p b}=1.35$ に達している。一方, 埋め込み型柱脚骨組で も, $\delta_{\max } / h=0.03$ 時では全層で梁降伏しているものの, 最下層柱脚部で 大きな塑性ヒンジを形成し, 柱脚部に損傷が集中し, 最終的には柱 崩壊を生じてしまう。

図 9 に層中間型柱脚 3 9 層ラーメン骨組の静的増分解析及び仮 想仕事法による保有水平耐力を比較している。 横軸は最大層間変形角である。縦軸は仮想仕 事法により求めた骨組の保有性能で, 歪硬化 を考慮していない $C_{v}(\tau=1.0)$ に対する数值解析 結果 $C_{a}$ の割合 $C_{a} / C_{v}$ である。図 $9(\mathrm{a})$ は 3 層骨組, 図 9(b)は 6 層骨組, 図 9(c)は 9 層骨組の場合 である。全ての図で層間変形角が大きくなるに つれて保有水平性能は高くなる。これは，図 8 から分かるように, 層間変形角の増加に伴い, 梁端の塑性化が進展していくためである。図 9 (a)で 3 層骨組では $\delta_{\max } / h=0.02$ のとき仮想仕事
法で歪硬化を考慮していない $C_{v}$ と数值解析結果の $C_{a}$ が柱梁耐力比 に関わらずほぼ等しいものの， 6 層，9層骨組では $C_{a}$ が $C_{v}$ を下回っ ており，この時点では全層梁降伏メカニズムを形成していないことが 分かる。図 9(b)の 6 層骨組では $\delta_{\max } / h=0.03$ 時に歪硬化を考慮してい ない $C_{v}$ と $C_{a}$ がほぼ等しくなっている。なお, 数值解析結果において 3 層骨組では $\delta_{\text {max }} / h=0.02$ のとき全層梁降伏型メカニズムを形成し た。 6 層骨組では $\delta_{\max } / h=0.02$ のとき 4 層より下層の全ての梁と 5 層の一部の梁で降伏し, $\delta_{\max } / h=0.03$ のとき 5 層より下層の全ての 梁と 6 層の一部の梁で降伏し, 部材崩壊時には全層梁降伏型メカ ニズムを形成した。 9 層骨組では $\delta_{\max } / h=0.02$ のとき 6 層より下層の 全ての梁で梁降伏し， $\delta_{\max } / h=0.03$ のとき 9 層骨組では 7 層より下 層の全ての梁と 8 層の一部の梁で降伏し, 部材崩壊時にはほとん どの骨組で全層梁降伏型メカニズムを形成した。本論文で提案す る柱脚機構は最下層中央でピン支持となっており, 柱が弾性であ れば高さ方向に損傷を分散させる心棒効果を発揮する。そのため, 層数の違いにより最大層間変形角と耐力上昇率の関係は $10 \%$ 程度 異なるものの，3 9 層程度の中低層骨組であれば，概ね $\delta_{\max } / h=0.02$ のとき $\tau=1.0, \quad \delta_{\max } / h=0.03$ のとき $\tau=1.1$ で評価できる。部材崩壊時に は全層梁降伏型メカニズムを形成し， $C_{a}$ が歪硬化を考虑した $C_{v}$ を上 回っている。図 5(a)で示されているように, 梁崩壊時の最大耐力は 全塑性モーメントの 1.3 倍以上に達するとともに, 骨組内の全て の梁端が降伏し, 歪硬化域にあるためである。そのため, 梁が十 分な塑性変形性能を有していれば，部材崩壊時の保有水平耐力は $\tau=1.3$ で概ね評価できる。

一方，埋め込み型柱脚骨組ではピン接合が柱に存在せず， 2.1 節 の方法で保有水平耐力を算出できないものの, 便宜的に(4)式の $h$, には提案型骨組と同じ值を用い，(1) 式には最下層柱脚も降伏す るものとして内部エネルギーを算出した。その結果, 全ての骨組 において $\delta_{\text {max }} / h=0.02,0.03$ 時で数值解析結果の $C_{a}$ が仮想仕事法に よる $C_{v}$ の 80 90\%程度となり，危険側となる。これは，図 8 からも

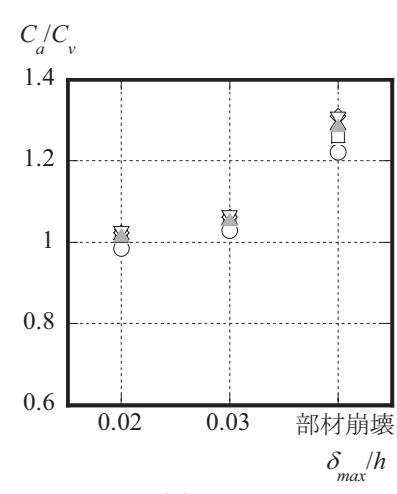

(a) 3 層骨組

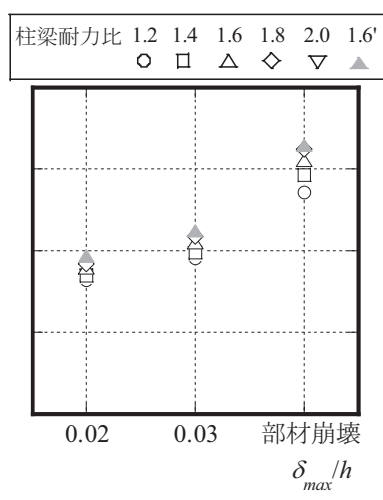

(b)6 層骨組

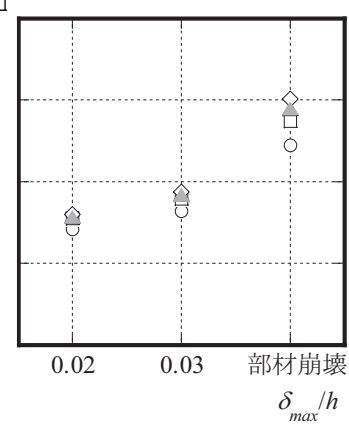

(c)9 層骨組

図 9 解析結果と仮想仕事法により求めた架構の保有水平耐力との比較 
分かるように，部材崩壊時までに全層の梁端 で降伏するものの, 層間変形角の増加に伴い, 柱脚での塑性化が著しくなり, 最下層柱脚で 部材崩壊するため, 層間変形角が大きくなって もべースシアはほとんど増加しないためである。 仮に便宜的に仮想仕事法を適用して骨組の保有 性能評価を試みても，その值は過大になる。

\section{3. 層中間型柱脚機構を有する中低層鉄骨ラーメン骨組の地震応答} 解析

本章では，ラーメン骨組の地震応答解析を行い，地震動の最大速 度と柱と梁の累積塑性変形倍率分布や最大累積塑性変形倍率を調心， これらの解析結果と 2 章で提示した仮想仕事法による保有水平耐力 評価を比較する。そして, 地震応答解析結果に対して, 仮想仕事法 による保有水平耐力評価の適用の可能性を検討するとともに，鉄骨 柱支点部に作用する軸力とせん断力の要求值を明らかにする。

\section{1 中低層鉄骨ラーメン骨組の地震応答解析概要}

鉄骨ラーメン骨組の粘性減衰は Rayleigh 型とし, 1 次と 2 次の減衰 定数は $2 \%$ と寸る。部材の構成則には移動硬化則を用いる。文献 3), 4)，6)と同様，3 スパンラーメン骨組の 1 層あたりの質量を 188.3 ton と寸る。地震応答解析では部材の初期軸力に対して P- $\delta$ 効果を考慮 しているが，変動軸力分については考慮していない。

表 3 に 3 9 層ラーメン骨組の固有周期を示寸。骨組の 1 次固有 周期は， 3 層で $0.651 \sim 0.690(\mathrm{sec}) ， 6$ 層で $0.955 \sim 0.987(\mathrm{sec}), 9$ 層 で $1.418 \sim 1.446(\mathrm{sec})$ 程度である。等しい柱梁耐力比で柱脚機構が 異なる場合, 固有周期の違いは最大 $5.4 \%$ 程度であった。地震応答 解析で用いる地震波は EL Centro 1940 NS/EW, Hachinohe 1968 NS/EW，Kobe 1995 NS/EW，Taft 1952 NS/EW の 8 種類とする。

図 10 に地震応答解析で用いた代表的な 4 種類の地震波（EL Centro 1940 NS, Hachinohe 1968 NS, Kobe 1995 NS, Taft 1952 NS) について最大速度 50kineに規準化した入力波の一質点系の弾性加 速度応答スペクトルを示す。減衰定数は $2 \%$ としている。地震応答 解析では時刻歴波形の最大速度を 50,75kine に基準化する。

\section{2 静的増分解析と地震応答解析による作用曲げモーメントの比} 較

図 11 に静的増分解析と地震応答解析より算出した，梁の作用曲げ モーメントの合計值を比較している。縦軸は地震応答解析結果，横 軸は静的増分解析結果であり, 地震応答解析結果は最大層間変形角

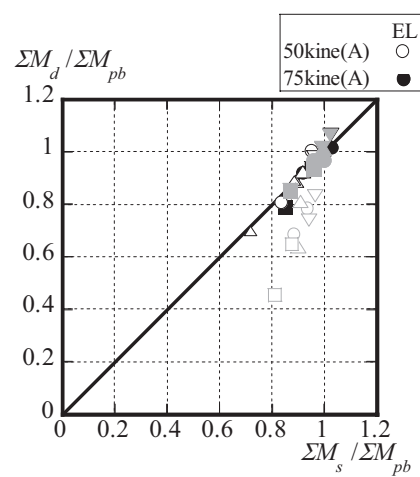

(a)3 層骨組

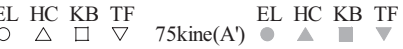

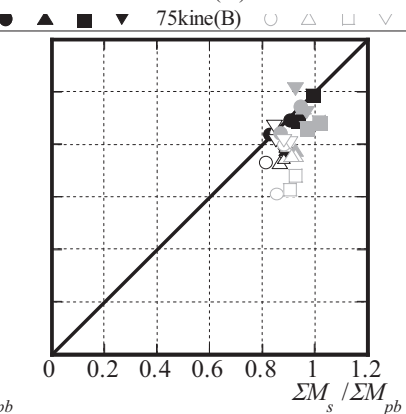

(b)6 層骨組

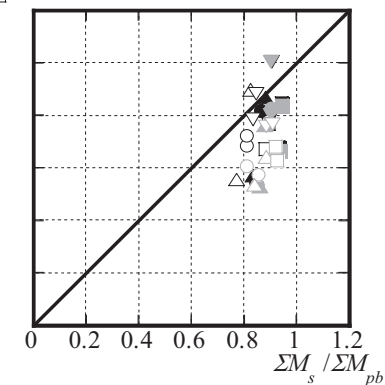

(c)9 層骨組
図 11 地震応答解析と静的解析の作用曲げモーメントの比較
表 3 骨組の固有周期 $(\mathrm{sec})$

\begin{tabular}{|c|c|c|c|c|c|c|c|}
\hline & B-3-1.4 & A-3-1.6 & B-3-1.6 & A-3-1.8 & B-3-1.8 & A-3-2.0 & B-3-2.0 \\
\hline 0.674 & 0.689 & 0.672 & 0.689 & 0.663 & 0.688 & 0.651 \\
\hline & 0.208 & 0.196 & 0.203 & 0.19 & 0.196 & 0.183 & 0.187 \\
\hline & B-6-1.4 & A-6-1.6 & B-6-1.6 & A-6-1.8 & B-6-1.8 & & \\
\hline & 0.976 & 0.984 & 0.965 & 0.981 & 0.955 & & \\
\hline & 0.326 & 0.322 & 0.318 & 0.318 & 0.313 & & \\
\hline & B-9-1.4 & A-9-1.6 & B-9-1.6 & A-9-1.8 & B-9-1.8 & & \\
\hline & 1.433 & 1.446 & 1.436 & 1.435 & 1.418 & & \\
\hline & 0.492 & 0.494 & 0.491 & 0.486 & 0.482 & & \\
\hline
\end{tabular}

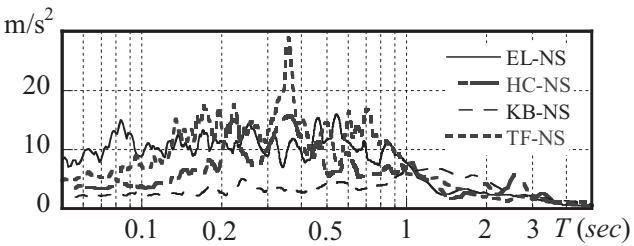

図 10 加速度応答スペクトル(最大速度を 50kine に規準化)

時の骨組内の各梁端の作用曲げモーメンの和 $\Sigma M_{d}$ を, 静的増分解析結 果は地震応答解析での最大層間変形角と等しいときの作用曲げモー メントの和 $\Sigma M_{s}$ を骨組内の全ての梁端が全塑性モーメント状態のと きの合計值 $\Sigma M_{p b}$ で除したものである。層中間型柱脚骨組では，最大 層間変形角を生じた層は第 2 層であった。 3 層ごとに部材断面を変更 した層中間型柱脚骨組の解析結果を黒プロット $\bigcirc, \triangle, \square, \nabla$,

$\boldsymbol{\Delta}, \boldsymbol{\square}, \boldsymbol{\nabla}$ で，2 層ごとに部材断面を変更した層中間型柱脚骨組の解 析結果及び埋め込み型柱脚骨組の解析結果を灰色プロット○， $\Delta$,

ロ み型柱脚骨組の結果も灰色プロット $\bigcirc, \triangle, \square, \nabla$ で示す。

図 11(a)3 層，(b)6 層の層中間型柱脚骨組では，地震応答解析結果 と静的増分解析結果はほぼ等しいものの, (c) 9 層層中間型柱脚骨組で は地震応答解析における曲げモーメントの合計值は, Hachinohe 1968 NS/EW, Kobe 1995 NS/EW で静的解析結果よりも25\%程度, 小さくなる傾向にある。2 層ごとに部材断面を変更した骨組の解析結 果は，3 層ごとに部材断面を変更した骨組と比べて最大 $10 \%$ 程度 の違いがある。一方，埋め込み型柱脚骨組では，最下層柱脚部で 降伏すると層間変形角の増加に伴い，損傷が集中する。縦軸の地 震応答解析における梁の作用曲げモーメントが横軸の静的増分解 析よりも低下しており，低層ほどこの傾向は顕著である。

以上より，本論文で提案する層中間型柱脚を適用した 2 4 スパ ン，3 9 層の整形なラーメン骨組に規準化観測地震動を入力した 場合，地震応答解析における梁端曲げモーメントの合計值は静的 増分解析結果とほぼ等しいため，その範囲では 2 章で得られた耐 力上昇率 $て$ で保有水平耐力を概水評価できる。 
図 12 に, 図 11 における静的増分解析と地震応答解析の層中間型 柱脚 6 層ラーメン骨組の層間変形角分布の一例を示している。横軸 は各層の層間変形角 $\delta_{i} / h$ である。縦軸は層数 $n$ である。図 $12(\mathrm{a})$ は $\mathrm{El}$ Centro NS 75kine, 図 12(b)は Hachinohe NS 75kine である。図 11 では, 地震応答解析結果と最大層間変形角が等しくなるときの静的増分解 析結果を比較している。図 12(a)では両解析の分布はほぼ等しいもの の, 図 12(b)では地震応答解析の外力分布が時系列的に変化するが, 最大層間変形角時には $\mathrm{Ai}$ 分布に比べて上層での外力分布が小さくな っているために, 地震応答解析の方が上層でより小さな層間変形角 となっている。そのため, 図 11 でEl Centro NS 75kine の場合, 静的 増分解析と地震応答解析の作用曲げモーメントの合計值はほぼ等し いものの, Hachinohe NS 75kine では地震応答解析の方が合計值は小 さくなっている。図 11 で多くの場合, 最大層間変形角が等しいとき, 最大作用曲げモーメントの合計值は地震応答解析結果に比べて静的 増分解析結果の方が大きくなっている。

\section{4 層中間型柱脚機構を有する中低層鉄骨ラーメン骨組における 鉄骨柱支点部の要求性能 \\ 4.1 柱曲げ剛性と柱作用曲げモーメント}

図 13 に柱梁耐力比 1.6 の層中間型柱脚 3 スパン 3 層ラーメン骨組 の側柱と中柱の最大作用曲げモーメント分布を示している。横軸 は柱の最大作用曲げモーメント $M_{c}$ を第 1 層の梁の全塑性モーメ ント $M_{p b 1}$ で除している。(a-1)〜 (a-3) は柱梁曲げ剛性比 $\alpha\left(=\left[\left(E I_{c} /(h / 2)\right] /\left[E I_{b} /(l / 2)\right]\right)=0.76,3.0,15.3\right.$ の最大層間変形角 $\delta_{\max } / h=$ 0.03 のときの静的増分解析結果であり,(b-1)〜 (b-3)は El Centro NS の地震応答解析結果, $(\mathrm{c}-1) \sim(\mathrm{c}-3)$ は Kobe NS $の$ 地震応答解析結果 である。ここで，柱梁曲げ剛性比 $\alpha$ とは最下層の梁の曲げ剛性 $E I_{b} /(l / 2)$ に対する柱の曲げ剛性 $E I_{c} /(h / 2)$ の比であり, $l / 2, h / 2$ は梁, 柱の反曲点長さ（スパン及び階高の半分）としている。表 2 に示 寸柱梁耐力比 1.6 の柱，梁断面を基準とすると，柱梁曲げ剛性比 $\alpha$ は 3 層骨組， 6 層骨組で 3.0, 9 層骨組で 2.8 である。そして, (a-1) $\alpha=0.76$ ，(a-3) $\alpha=15.3$ の柱断面二次モーメント $I_{c}$ は基準である (a-2) $\alpha=3.0$ に対して 0.25，5 倍としたものである。文献 6)で柱梁 曲げ剛性比が柱の高さ方向のモーメント分布に影響を及ぼすこと が明らかにされていることから，本論文でも柱梁曲げ剛性比をパ ラメータとして第 1 層梁に取り付く側柱と中柱のモーメント分布 を調べる。なお, 前章及び文献 3) 6) では最大層間変形角 $\delta_{\max } / h=0.03$ までは全ての柱で弾性保持し，さらに部材崩壊時まで第 1 層梁に 取り付く柱端は降伏していない。そこで, 柱を弾性として曲げ剛性と曲げモーメント 分布の関係を検討する。

静的増分解析及び地震応答解析の最大 層間変形角時の曲げモーメント分布を実線 で，地震応答解析の時刻歴において各節点 でモーメントが最大となったときの值を正 負それぞれについて，灰色の塗りつぶしで 示している。図 13(a)静的増分解析結果では, (a-1) $\alpha=0.76$ の中柱で第 2 層, 第 3 層の反曲 点はほぼ柱中央にあり, 曲げモーメント分 布はほぼ逆対称分布になるが，(a-3) $\alpha=15.3$

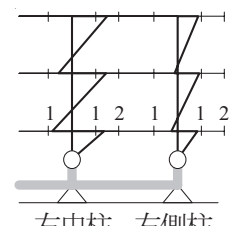

右中柱 右側柱 (a-1) $\alpha=0.76$

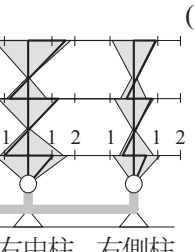

右中柱 右側柱 (b-1) $\alpha=0.76$

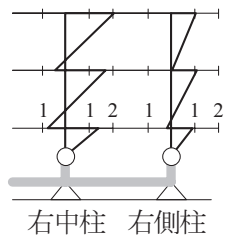

(a-2) $\alpha=3.0$ (a)静的解析結果 $(\delta$

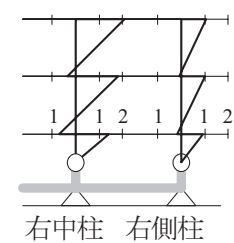

(a-3) $\alpha=15.3$ $=0.03$ )

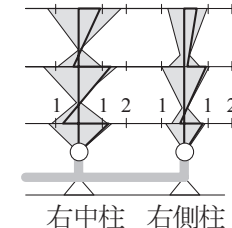

(b-2) $\alpha=3.0$

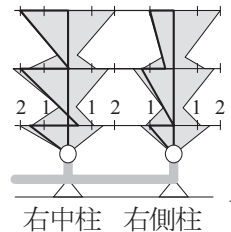

(b-3) $\alpha=15.3$
(b)地震応答解析結果(EL Centro NS 75kine)

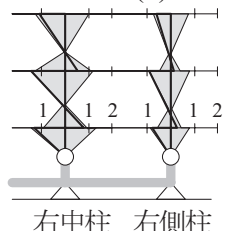

(c-1) $\alpha=0.76$

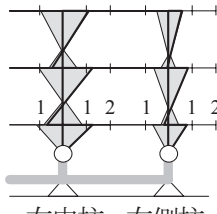

右中柱 右側柱

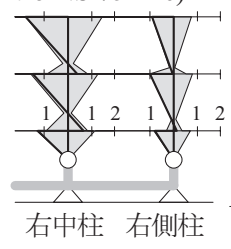

(c-3) $\alpha=15.3$
(c)地震応答解析結果(Kobe NS 75kine)

図 13 柱の最大曲げモーメント分布

の中柱では反曲点が中央よりも下側となっている。また， (a-2) $\alpha=3.0$ の側柱, (a-3) $\alpha=15.3$ 側柱では第 2 層, 第 3 層の反曲点 は中柱よりも下がっており, 第 2 層, 第 3 層の柱脚曲げモーメン トはほぼ 0 となっている。つまり, 側柱では柱に取りつく梁の曲 げモーメントは第 1 層, 第 2 層の柱頭に伝達されており, 最下層 柱頭の最大曲げモーメントは梁の最大曲げモーメントにほぼ等し くなっている。地震応答解析結果では, 柱梁曲げ剛性比が小さい とき, 第 2 層, 第 3 層の反曲点はほぼ柱の中央となっているが, 柱梁曲げ岡性比が大きいとき, 第 2 層, 第 3 層の反曲点が層の下 側に移動している。

図 14 に, 図 13 の層中間型柱脚ラーメン骨組における最下層中柱 と側柱の柱頭の最大曲げモーメントを示寸。図 14(a)〜 (c)は 3 層, 6 層, 9 層骨組について示している。縦軸は, 柱に取り付く第 1 層梁の全塑性モーメントに対寸る最下層柱頭の最大モーメントの 割合 $M_{c 1} / M_{p b 1}$ である。横軸は柱梁曲げ剛性比 $\alpha$ である。各線は静 的増分解析で最大層間変形角 $\delta_{\max } / h=0.02,0.03$, 部材崩壊時の柱曲 げモーメント比を示しており, 各プロットは最大速度 75kine の動 的応答解析における最大層間変形角時の柱曲げモーメント比を示

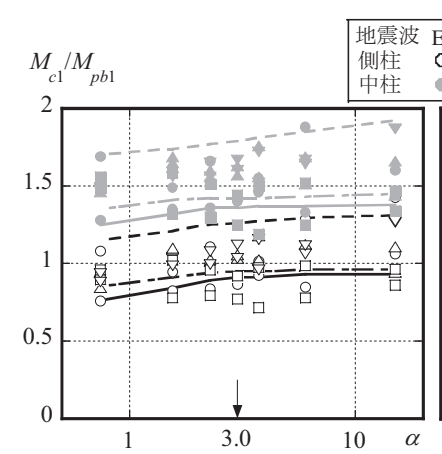

(a) 3 層骨組

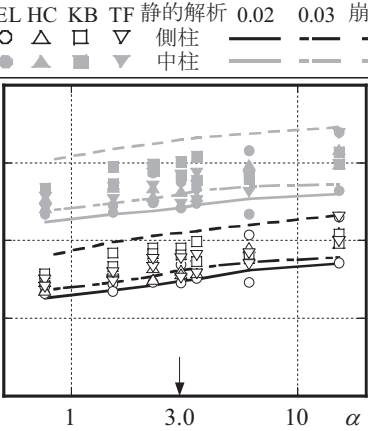

(b) 6 層骨組

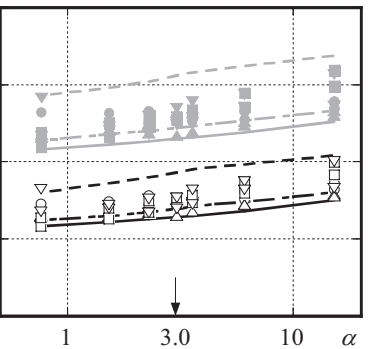

(c) 9 層骨組

図 14 最下層柱頭の最大曲げモーメント 
している。灰色プロットが中柱, 白プロット が側柱である。また, 図中, 横軸の矢印 $(\alpha=3.0)$ は基準モデルの值を示している。静的増分解

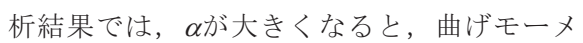
ントは緩やかに上昇している。地震応答解析 結果ではばらつきがみられるものの, 静的増 分解析結果と同様の傾向を示し, 柱梁曲げ岡 性比の違いが最下層柱脚の曲げモーメントに 及ぼす影響は小さい。 $\alpha=3.0$ では中柱の最下 層柱頭の最大曲げモーメント比 $M_{c 1} / M_{p b 1}$ は, 静的増分解析で $\delta_{\max } / h=0.03$ のとき 1.2 1.4 程 度, 部材崩壊時には 1.6 1.8 程度に達する。

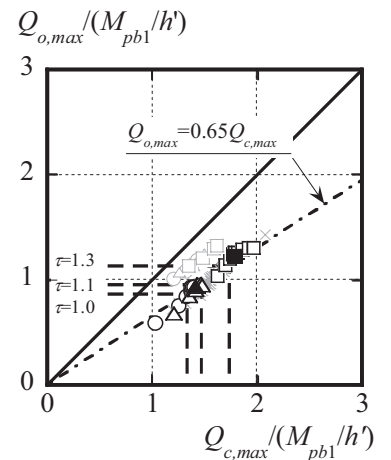

(a) 3 層骨組

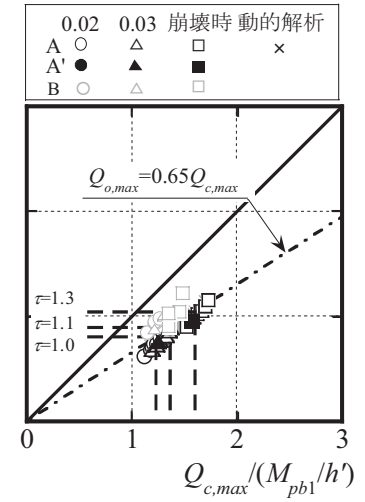

(b) 6 層骨組

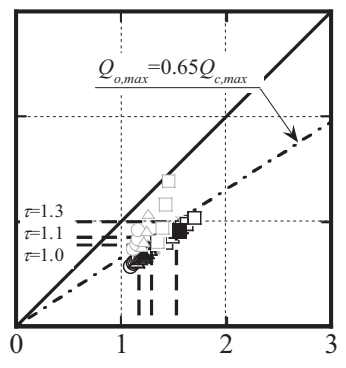

$Q_{c, \max } /\left(M_{p b 1} / h^{\prime}\right)$

(c) 9 層骨組

図 15 側柱と中柱のせん断力比の比較

ができる。

一方, 埋め込み型柱脚骨組では負担せん断力の割合は 3 層骨組 で $80 \% ， 6$ 層骨組 $70 \% ， 9$ 層骨組で $85 \%$ 程度であり，特に 9 層骨 組では柱梁耐力比の違いにより $60 \%$ $95 \%$ とばらついている。埋め 込夕型柱脚骨組の場合, 例えば, 柱梁耐力比 1.6 の 層骨組の中 柱の柱脚部では最大層間変形角 $\delta_{\text {max }} / h=0.0085$ のとき降伏し, 側柱 では $\delta_{\max } / h=0.01$ のとき降伏している。最下層中柱の柱脚部，側柱 の柱脚部の順に降伏することで，中柱と側柱のせん断力の負担割 合が最大層間変形角の大きさによって変化するため, 負担せん断 力の割合を最大層間変形角によらず求めることは難しい。

次に, 2 章の仮想仕事法を用いて, 鉄骨柱支点部の作用せん断 力を求める。ベースシアと最下層中柱と側柱のせん断力の関係は 次式で表される。

$$
Q_{1}=C_{v} \cdot A_{1} \cdot W_{1}=\sum_{j=1}^{m-1} Q_{c 1 j}+\sum_{k=1}^{2} Q_{o l k}
$$

ここで， $Q_{1}$ はベースシアであり， $Q_{c 1 j}, Q_{o 1 k}$ は最下層のそれぞれの 中柱, 側柱のせん断力である。また, $m$ はスパン数である。ここ で中柱の $Q_{c 1 j}$ は柱位置 $(j)$ にらず全て等しく, 側柱の $Q_{o 1 k}$ も柱左 右の位置 $(k)$ によらす等しいものとする。図 15 より, 中柱と側柱 のせん断力の関係を $Q_{o 1 k}=0.65 Q_{c 1 j}$ とすると，(6)式は次式となる。 $Q_{1}=(m-1) Q_{c 1 j}+1.3 Q_{c 1 j}=(m+0.3) Q_{c 1 j}$

(5)式で得られる $C_{v}$ を(2)式の $Q_{i}(i=1)$ に代入することで, ベース シア $Q_{1}$ が求められ, (7)式より中柱及び側柱のせん断力 $\Sigma Q_{c 1 j}, \Sigma Q_{o 1 k}$ が求められる。図中の縦軸, 横軸からの破線は, (7)式より求めた 中柱, 側柱の層せん断力である。3 本の線はそれぞれ耐力上昇率 $\tau=1.0,1.1,1.3$ である。 3 層骨組の部材崩壊時のとき, 各線は数 值解析結果よりも低くなっているものの, 9 層骨組では仮想仕事 法は数值解析結果よりも高く, 安全側の評価となる。3 層, 6 層骨 組では, $\tau=1.0,1.1$ として仮想仕事法より求めた中柱と側柱のせ 几断力と数值解析結果における最大層間変形角 $\delta_{\max } / h=0.02,0.03$ のときのせん断力は概衩対応しており，仮想仕事法により鉄骨柱 支点部の最大作用せん断力を簡便に求めることができる。

\section{3 仮想仕事法による鉄骨柱支点部の作用圧縮力評価}

図 16 に3 9 層ラーメン骨組の最下層柱に作用寸る最大軸力比を 示す。図 16(a)〜 (c) は 3 層, 6 層, 9 層骨組について示している。 縦軸は中柱及び側柱の最大作用軸力 $N_{c 1, \text { max }}, N_{o 1, \text { max }}$ を基準モデルの 最下層鉄骨柱の降伏軸力 $N_{c l y}\left(=A_{c} \sigma_{c y}\right)$ で除したものである。横軸は 
図 14 と同様である。各線は静的増分解析 で最大層間変形角 $\delta_{\max } / h=0.02,0.03$, 部材 崩壊時の軸力比を示している。各プロッ ト, 各線は図 14 と同様である。縦軸には 柱の初期軸力を示しており, 建物の自重 による側柱の初期軸力比は $N_{o 1} / N_{c 1 y}=0.15$ $\sim 0.2$ 程度で中柱はその倍となる。柱梁 曲げ剛性比が基準モデルよりも大きい範 囲では, 最大層間変形角 $\delta_{\max } / h=0.02,0.03$, 梁崩壊時の中柱の最大圧縮力比は初期軸 力比とほぼ等しく, 軸力変動はほとんど

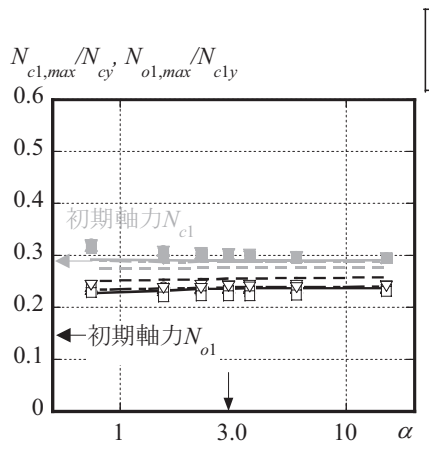

(a) 3 層骨組

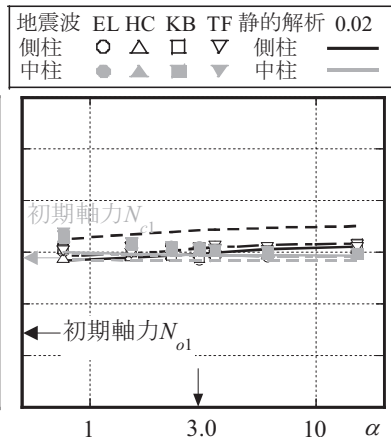

(b) 6 層骨組

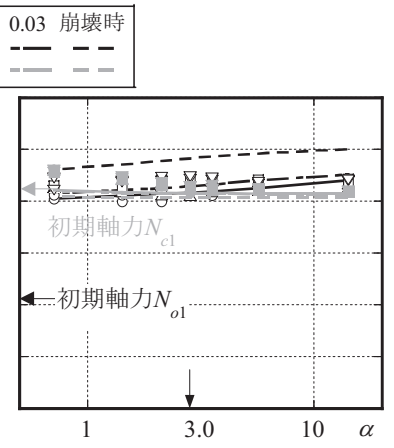

(c) 9 層骨組

図 16 鉄骨柱支点部の最大軸力比（3 スパン）

\section{生じていない。なお, スパン数による違}

いについても軸力を検討したが，3 スパンの結果とほぼ同様の傾 向を示した。側柱でも柱梁曲げ剛性比の違いが軸力比に及ぼす影 響は小さいものの, 柱梁曲げ岡性比が大きくなるにつれて軸力比 は緩やかに大きくなる。通常の中低層骨組の水平変形では, 柱の 軸伸縮による骨組の曲げ変形に比べて層間変形の占める割合が大 きいものの, 柱の曲げ岡性が大きくなるに従って曲げ変形型に移 行するためと考えられる。柱梁曲げ剛性比が基準モデルよりも大 きい範囲では, 最大作用軸力比は等しく, スパン数によらず最大 層間変形角 $\delta_{\max } / h=0.03$ までは 3 層, 6 層, 9 層骨組の側柱の最大軸 力比は $N_{o 1, \text { max }} / N_{c 1 y}=0.3,0.35,0.45$ 程度, 部材崩壊時で $N_{o 1, \text { max }} / N_{c 1 y}=0.3$, $0.4,0.55$ 程度である。

一方, 2 層ごとに部材断面を変更した骨組では, 部材崩壊時の 中柱の軸力比 $N_{c 1, \text { max }} / N_{c y}$ は 3 層骨組で $0.20,6$ 層骨組で $0.27,9$ 層 骨組で 0.41 程度であり, 側柱の軸力比 $N_{o 1, \text { max }} / N_{c 1 y}$ は 3 層骨組で 0.19 , 6 層骨組で $0.32,9$ 層骨組で 0.48 程度である。6 層, 9 層骨組では 3 層ごとに部材断面を変更した骨組とほぼ等しくなったが, 3 層骨 組では変動軸力はほぼ等しいものの, 降伏軸力 $N_{c 1 y}$ の值が異なる ため, 最大軸力比が小さくなった。

4.1 節と同様, 2 章の仮想仕事法を用いて, 鉄骨柱支点部の作用 軸力を求める。鉄骨柱支点部の転倒モーメントの釣り合いから, 水平外力と柱の軸力の関係は(2), (3)式より次式で表される。

$$
\sum_{i=1}^{n} i \cdot h \cdot F_{i}=\sum_{j=1}^{(m+1) / 2}(m / 2-j+1) \cdot l \cdot N_{j} / 2
$$

$m$ は骨組のスパン数, $h$ は層高さ, $l$ はスパン長, $N_{j}$ は水平外力に 伴う柱の変動軸力である。ここで, $(m+1) / 2$ が整数でないとき, 小 数点以下を切捨てとする。数值解析結果 から, (8)式では中柱の変動軸力は過大に, 側柱の変動軸力は過小に評価してしまう。 図 16 から 4 スパン程度であれば, 最下層 中柱の軸力変動はほとんどないことから， (8)式で中柱の $N_{c j}=0$ として最下層側柱の 変動軸力を求めると次式となる。

$$
\Delta N_{o}=\frac{2}{m \cdot l} \sum_{i=1}^{n} i \cdot h \cdot F_{i}
$$

ここで, $F_{i}$ は $\mathrm{Ai}$ 分布より求められる $i$ 層 の水平外力である。

図 17 は側柱と中柱の初期軸力 (建物の 自重）及び水平外力による変動軸力の関

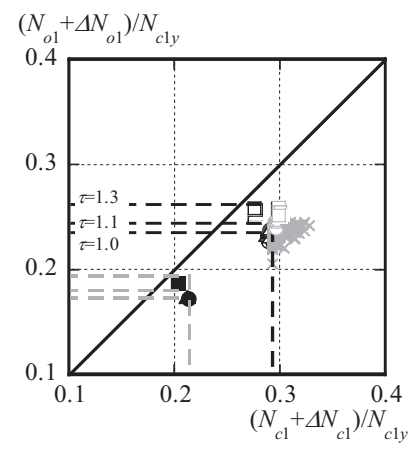

(a) 3 層骨組
係を示している。縦軸は最下層側柱の初期軸力 $N_{o 1}$ と変動軸力 $\Delta N_{o 1}$ の和, 横軸は最下層中柱の初期軸力 $N_{c 1}$ と変動軸力 $\Delta N_{c 1}$ の和を最 下層柱の降伏軸力 $N_{c 1 y}$ で除したものである。なお, 比較のため, 埋

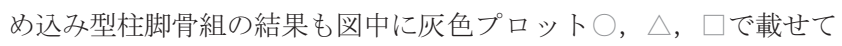
いる。各プロットは図 15 と同様である。また, 図中の縦軸, 横軸 からの黒破線は, (9)式より求めた, 3 層ごとに断面を変更した骨 組の側柱の軸力であり, 3 本の線はそれぞれ耐力上昇率 $\tau=1.0,1.1$, 1.3 である。同様に, 灰色破線は 2 層ごとに断面を変更した層中間 型柱脚骨組の側柱の軸力であり, 図 17(b), 図 17(c)では黒破線と 等しい值になっている。層中間型柱脚 3 層骨組では, 柱梁耐力比 の違いによるばらつきは少なく, 最大層間変形角 $\delta_{\max } / h=0.02,0.03$, 部材崩壊のとき，それぞれ $\tau=1.0,1.1,1.3$ にほぼ対応している。 なお, 2 層ごとに部材断面を変更した骨組の数值解析結果は, 層 中間型柱脚 6 層, 9 層骨組では 3 層ごとに部材断面を変更した骨組 とほぼ等しい。層中間型柱脚 3 層骨組では変動軸力值はほぼ等し いものの, それぞれの骨組で降伏軸力 $N_{c 1 y}$ の值が異なるため, 2 層ごとに部材断面を変更した層中間型柱脚骨組の作用軸力比は, 3 層ごとに部材断面を変更した骨組の軸力比に比べて小さくなって いる。最大層間変形角 $\delta_{\max } / h=0.02,0.03$, 部材崩壊のとき, 骨組の 層数や柱断面の違いによらず, それぞれ $\tau=1.0,1.1,1.3$ にほぼ対 応している。また, 図 15 のせん断力の場合と同様, 層中間型柱脚 6 層, 9 層骨組では, 仮想仕事法により求めた側柱の鉄骨柱支点部 の作用軸圧縮力は数值解析結果よりも大きく, 安全側の評価とな る。仮想仕事法により鉄骨柱支点部の最大作用軸圧縮力を簡便に 求めることができる。

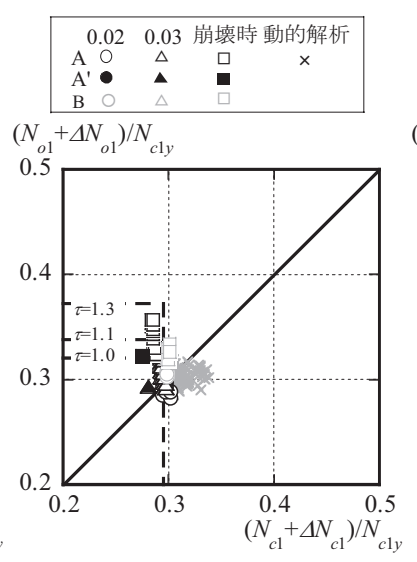

(b) 6 層骨組

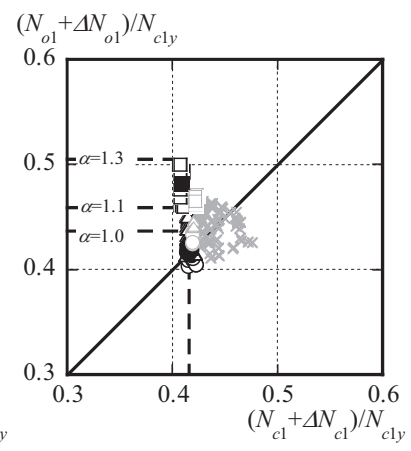

(c) 9 層骨組
図 17 側柱と中柱の鉄骨柱支点部の最大軸力比 
一方，埋め込み型柱脚骨組の中柱については軸力がほとんど変動 せず，層中間型柱脚骨組の場合とほぼ等しい。側柱については軸 力比が小さい 3 層骨組で最大層間変形角 $\delta_{\max } / h=0.02,0.03$, 部材崩 壊のとき, それぞれ $\tau=1.0,1.1,1.3$ にほぼ対応しているが, 軸力 比が大きい 6 層, 9 層骨組では最下層柱脚部の降伏及び部材崩壊 が早期に生じるため，作用軸力が増加せず $\tau=1.3$ よりも小さくな っている。埋め込久型柱脚骨組の場合, 骨組の層数や柱梁耐力比 等の違いによって作用軸力比は大きくばらつくことから，(9)式の 適用は難しい。

\section{5. 結}

層中間型柱脚機構を有する鉄骨ラーメン骨組の保有水平性能の 簡易評価方法として仮想仕事法を適用し，静的増分解析及び地震 応答解析によりその有効性を確認した。さらに，鉄骨柱支点部に 作用する最大せん断力及び最大軸力を求め, 鉄骨柱支点部の要求 性能を明らかにした。以下に得られた結論を示す。

1)骨組の最大層間変形角 0.02 では，歪硬化を考慮しない全層梁降伏 と仮定した内部歪エネルギーを用いることで仮想仕事法により骨 組の保有水平耐力を評価できる。さらに，部材崩壊時では歪硬化を 考慮した仮想仕事法により骨組の保有水平耐力を評価できる。

2) 地震応答解析では上層で層間変形角が小さくなるため, 最大層間 変形角が等しいときの骨組内の塑性モーメントの合計值は, 地震応 答解析よりも静的増分解析の方で概ね大きくなる。

3)仮想仕事法により得られるベースシアと数值解析から得られた側 柱と中柱のせん断力負担比の関係から鉄骨柱支点部の最大作用せ 几断力を簡易的に求めることができる。さらに, 想定する最大層間 変形角時 $(0.02 ， 0.03$, 部材崩壊時 $)$ の鉄骨柱支点部の必要せん断 耐力は, 仮想仕事法により求められる歪硬化係数 $1.0,1.1,1.3$ の ときの值にほぼ対応している。

4)仮想仕事法より得られる水平外力による転倒モーメントを側柱 と中柱に作用する偶力として捉えることで, 鉄骨柱支点部の最大 作用圧縮力を求められる。作用せん断力の場合と同様, 想定する 最大層間変形角 $(0.02 ， 0.03$ ，部材崩壊時）レベルの鉄骨柱支点 部の必要軸圧縮耐力は, 仮想仕事法により求められる歪硬化係数 1.0１.1，1.3のときの值にほぼ対応している。

本論文で得られた知見の適用範囲は，提案する柱脚機構を適用し， 最下層柱脚部は降伏せず，中間層の柱もほぼ弾性となる，柱梁而 力比 1.2 2.0 で 2 4 スパン 3 9 層の整形な鉄骨ラーメン骨組を対象 とし，梁及び柱が十分な塑性変形性能を有する場合である。

\section{参考文献}

1）国土交通省住宅局建築指導課，日本建築主事会議，日本建築セン夕 一: 2007 年度版建築物の構造関係技術基準解説書, 2007

2) 島田侑子, 吹田啓一郎, 山田哲, 松岡祐一, 多田元英, 大崎純, 笠井和彦：振動台実験における倒壊挙動 一実大 4 層鉄骨造建物 の完全崩壊実験 その 3 -, 日本建築学会構造系論文集, 第 75 巻 第 653 号, pp.1351-1360, 2010.7

3）金田勝德，木村祥裕，濱崎慎一，和田章：全層梁降伏型を目指した中 低層鉄骨ラーメン構造構築のための新しい柱脚機構の提案，日本建築 学会構造系論文集, 第 75 巻第 654 号, pp.1537-1546, 2010.8

4) 金田勝德，木村祥裕，宮原直樹，和田章：新しい柱脚機構を有する 中低層鉄骨ラーメン架構の終局耐震能力, 日本建築学会構造系論文
集，第 76 卷第 661 号，pp.649-658，2011.3

5) 金田勝徳, 木村祥裕, 六倉賢太, 角屋治克, 渡辺烹, 高橋邦広 : 全層 梁降伏型中低層鉄骨ラーメン構造構築のための柱脚機構に関する部 分架構モデルによる基礎実験, 日本建築学会構造系論文集, 第 76 巻第 665 号, pp.1357-1366, 2011.7

6) 木村祥裕, 金田勝徳, 和田章 : 新しい柱脚支持機構を有寸る鉄骨ラーメ ン骨組の終局耐震能力及び柱の要求性能評価に対寸る魚骨型骨組の 適用, 日本建築学会構造系論文集, 第 77 巻第 675 号, pp.765-773, 2012.5

7) 日本建築学会 : 鉄筋コンクリート構造計算規準・同解説， 1988

8) 日本建築学会: 建築耐震設計における保有耐力と変形性能 (1990), 1990

9) 加藤勉, 秋山宏, 帯洋一 : 局部座屈を伴う $\mathrm{H}$ 形断面部材の変形, 日本建 築学会論文報告集，第 257 号, pp.49-58, 1977.7

10) 加藤勉, 秋山宏, 北沢進 : 局部座屈を伴う箱形断面部材の変形, 日本建 築学会論文報告集，第 268 号，pp.71-76，1978.6

11) 木村祥裕 : 局部座屈崩壊型 $\mathrm{H}$ 形鋼梁の塑性変形性能と累積塑性変形 性能に及ぼす載荷履歴特性の影響, 日本建築学会構造系論文集, 第 76 巻第 664 号, pp.1143-1152, 2011.6

12) 山田哲, 秋山宏, 桑村仁: 局部座屈を伴う箱形断面鋼柱部材の変動 軸力下における終局挙動，日本建築学会構造系論文集，第 461 号， pp.115-122, 1994.7

13) 山崎真司, 見浪進 : 変動軸力と繰返し水平力を受ける鋼柱の弾塑性 挙動に関する実験的研究, 日本建築学会構造系論文集, 第 519 号, pp. $95-102, \quad 1999.5$

\section{Appendix 解析対象の柱及び梁の最大耐力と塑性変形性能}

付表 1 に本論文で用いた柱, 梁の最大耐力及び塑性変形性能の一覧を示 す。表中の最大耐力及び塑性変形性能については, 構成板要素の幅厚比, 材長等をパラメータとした文献 9) 11)の荷重変位関係の実験式より算出 している。A，B タイプの梁断面については 3 層, 6 層, 9 層骨組ごとにで きるだけ同じ断面を使用し, 層数が同じ骨組であれば，最大耐力及び塑性 変形性能がほぼ等しくなるようにしている。柱断面についても，実験式 ${ }^{11)}$ により求められる塑性変形性能をできるだけ等しくなるように設定してい るが, 初期軸力の影響により一部の下層柱の塑性変形性能は小さい。なお, 柱については部材崩壊が中柱で生じたため, 軸力変動をほとんど生じてお らず，塑性変形性能の大幅な低下は見られなかった。

付表 1 解析対象の柱・梁の最大耐力と塑性変形性能

\begin{tabular}{|c|c|c|c|c|c|c|c|c|c|}
\hline \multirow{2}{*}{$\frac{\text { 名称 }}{\text { Story }}$} & & \multicolumn{2}{|c|}{ A-3-1.2, B-3-1.2 } & \multicolumn{2}{|c|}{ A-3-1.4, B-3-1.4 } & \multicolumn{2}{|c|}{ A-3-1.6, B-3-1.6 } & \multicolumn{2}{|c|}{$\begin{array}{c}\text { A-3-1.8, B-3-1.8 } \\
(\mathrm{A}-3-2.0, \text { B-3-2.0) }\end{array}$} \\
\hline & & $M_{\max } / M_{P}$ & $\theta_{\max } / \theta_{P}$ & $M_{\max } / M_{P}$ & $\theta_{\max \gamma} \gamma \theta_{p}$ & $M_{\max } / M_{P}$ & $\theta_{\max } / \theta_{P}$ & $M_{\max } / M_{P}$ & $\theta_{\max } / \theta_{P}$ \\
\hline \multirow[t]{2}{*}{ 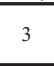 } & 柱 & \begin{tabular}{|l|}
1.28 \\
\end{tabular} & \begin{tabular}{|l|l|}
8.64 \\
\end{tabular} & \begin{tabular}{|l|}
1.26 \\
\end{tabular} & \begin{tabular}{|l|l|}
8.15 \\
\end{tabular} & 1.27 & 8.65 & $1.27(1.27)$ & $8.31(8.64)$ \\
\hline & 梁 & 1.44 & 15.7 & 1.44 & 15.7 & 1.44 & 15.7 & $1.44(1.44)$ & $15.7(15.7)$ \\
\hline \multirow{2}{*}{$1 \sim 2$} & 柱 & 1.28 & 8.64 & 1.26 & 8.15 & 1.27 & 8.65 & $1.27(1.27)$ & $8.31(8.64)$ \\
\hline & 梁 & 1.35 & 12.6 & 1.34 & 12.3 & 1.35 & 12.7 & $1.36(1.34)$ & $12.9(12.4)$ \\
\hline \multirow{2}{*}{$\begin{array}{l}\text { 名称 } \\
\text { Story }\end{array}$} & & \multicolumn{2}{|c|}{$\mathrm{A}-6-1.2, \mathrm{~B}-6-1.2$} & \multicolumn{2}{|c|}{$\mathrm{A}-6-1.4, \mathrm{~B}-6-1.4$} & \multicolumn{2}{|c|}{ A-6-1.6, B-6-1.6 } & \multicolumn{2}{|c|}{ A-6-1.8, B-6-1.8 } \\
\hline & & $M_{\max } / M_{P}$ & $\theta_{\max } / \theta_{P}$ & $M_{\max } / M_{P}$ & $\theta_{\max } \gamma \theta_{P}$ & $M_{\max } / M_{P}$ & $\theta_{\max } / \theta_{P}$ & $M_{\max } / M_{P}$ & $\theta_{\max } / \theta_{P}$ \\
\hline \multirow{2}{*}{6} & 柱 & \begin{tabular}{|l|}
1.27 \\
\end{tabular} & 8.81 & \begin{tabular}{|l|}
1.26 \\
\end{tabular} & \begin{tabular}{|l|l|}
8.46 \\
\end{tabular} & 1.26 & 8.59 & 1.25 & 8.24 \\
\hline & 梁 & 1.44 & 15.5 & 1.35 & 12.6 & 1.35 & 12.7 & 1.35 & 12.7 \\
\hline \multirow{2}{*}{5} & 柱 & 1.27 & 8.81 & 1.26 & 8.46 & 1.26 & 8.59 & 1.25 & 8.24 \\
\hline & 梁 & 1.34 & 12.3 & 1.35 & 12.6 & 1.33 & 12.1 & 1.34 & 12.3 \\
\hline \multirow{2}{*}{4} & 柱 & 1.27 & 8.81 & 1.2 & 8.46 & 1.26 & 8.59 & 1.25 & 8.24 \\
\hline & 梁 & 1.34 & 12.3 & & 12.6 & & 12.1 & 1.34 & 12.3 \\
\hline \multirow{2}{*}{3} & 柱 & 1.33 & 8.63 & 1.32 & 8.73 & 1.23 & 6.55 & 1.34 & 9.24 \\
\hline & 梁 & 1.34 & 12.5 & 1.35 & 12.7 & 1.34 & 12.4 & 1.35 & 12.6 \\
\hline \multirow{2}{*}{$1 \sim 2$} & 柱 & 1.33 & 8.63 & 1.32 & 8.73 & 1.23 & 6.55 & 1.34 & 9.24 \\
\hline & 梁 & 1.34 & 12.5 & 1.35 & 12.7 & 1.34 & 12.4 & 1.35 & 12.6 \\
\hline 名称 & & \multicolumn{2}{|c|}{ A-9-1.2, B-9-1.2 } & \multicolumn{2}{|c|}{ A-9-1.4, B-9-1.4 } & \multicolumn{2}{|c|}{ A-9-1.6, B-9-1.6 } & \multicolumn{2}{|c|}{ A-9-1.8, B-9-1.8 } \\
\hline Story & & $M_{\max } / M_{P}$ & $\theta_{\max } / \theta_{P}$ & $M_{\max } / M_{P}$ & $\theta_{\max } \backslash \theta_{P}$ & $\overline{M_{\max } / M_{P}}$ & $\theta_{\max } / \theta_{P}$ & $M_{\max } / M_{P}$ & $\theta_{\max } / \theta_{P}$ \\
\hline \multirow{2}{*}{9} & 柱 & $\begin{array}{l}1.28 \\
\end{array}$ & \begin{tabular}{|l|l|}
8.97 \\
\end{tabular} & $\begin{array}{ll}1.27 \\
\end{array}$ & $\begin{array}{l}8.64 \\
\end{array}$ & 1.28 & 8.94 & 1.26 & 8.42 \\
\hline & 梁 & 1.47 & 16.6 & 747 & 16.6 & & 18.0 & 1.51 & 18.0 \\
\hline \multirow{2}{*}{$7 \sim 8$} & 柱 & 1.28 & 8.97 & 1.27 & 8.64 & 1.28 & 8.94 & 1.26 & 8.42 \\
\hline & 梁 & 1.35 & 12.5 & 1.34 & 12.3 & 1.33 & 11.9 & 1.33 & 11.9 \\
\hline \multirow{2}{*}{$5 \sim 6$} & 柱 & 1.31 & 8.09 & 1.31 & 8.21 & 1.31 & 8.53 & 1.22 & 6.34 \\
\hline & 梁 & 1.35 & 12.7 & 1.34 & 12.4 & 1.33 & 12.1 & 1.34 & 12.2 \\
\hline \multirow[b]{2}{*}{. } & 柱 & 1.31 & & & & & 8.53 & 1.22 & 6.34 \\
\hline & 梁 & 1.35 & 12.7 & 1.34 & 12.4 & 1.33 & 12.1 & 1.34 & 12.2 \\
\hline & 柱 & 1.31 & 7.88 & 1.31 & 7.97 & 1.30 & 8.07 & 1.30 & 8.18 \\
\hline & 梁 & 1.33 & 12.0 & 1.34 & 12.3 & 1.35 & 12.6 & 1.35 & 12.7 \\
\hline \multirow{2}{*}{$1 \sim 2$} & 柱 & 1.31 & 7.88 & 1.31 & 7.97 & 1.30 & 8.08 & 1.30 & 8.18 \\
\hline & 梁 & 1.33 & 12.0 & 1.34 & 12.3 & 1.35 & 12.6 & 1.35 & 12.7 \\
\hline
\end{tabular}

